TITLE:

\title{
GENUS AMBLYELEOTRIS (GOBIIDAE) OF JAPAN AND GEOGRAPHICAL VARIATIONS OF A. JAPONICA TAKAGI
}

\section{$\operatorname{AUTHOR(S):~}$}

Yanagisawa, Yasunobu

\section{CITATION:}

Yanagisawa, Yasunobu. GENUS AMBLYELEOTRIS (GOBIIDAE) OF JAPAN AND GEOGRAPHICAL VARIATIONS OF A. JAPONICA TAKAGI. PUBLICATIONS OF THE SETO MARINE BIOLOGICAL LABORATORY 1976, 23(1-2): 145-168

\section{ISSUE DATE:}

1976-07-31

URL:

http://hdl.handle.net/2433/175917

RIGHT: 


\title{
GENUS AMBLYELEOTRIS (GOBIIDAE) OF JAPAN AND GEOGRAPHICAL VARIATIONS \\ OF A. JAPONICA TAKAGI ${ }^{1)}$
}

\author{
YASUNOBU YANAGISAWA \\ Seto Marine Biological Laboratory
}

With Text-figures $1-11$ and Tables 1-3

The genus Amblyeleotris was established by Bleeker (1874) for the sole species Amblyeleotris periophthalmus Bleeker (1853), on which Weber (1913), Koumans (1953) and Smith (1958) gave some further descriptions. A. japonica was described by Takagi (1957) on the specimens collected from Kagoshima Bay, Japan. The habitat and behaviour of this species, however, had not been known precisely, until Harada (1969) found that this gobioid fish inhabited the burrow dug by the snapping shrimp Alpheus bellulus Miya and Miyake (1969) on the sandy bottom in the shallow water of Shirahama. This gobioid fish stays near the entrance of the burrow, while the snapping shrimp dumps a load of sand outside the burrow in the daytime. The relationship between these two animals is intimate and they have developed the so-called alarm system, that is, the gobioid fish quivers the caudal part when an unusual situation is perceived, and the snapping shrimp which is always making contact with the gobioid fish by one of the antennae outside the burrow responds to this quivering and disappears deep inside the burrow instantaneously.

Several species of the gobioid fish and of the snapping shrimp have been known to be in association in the Red Sea (Luther, 1958; Magnus, 1967; Karplus et al., 1972). On the southern coast of Japan, four species of the gobioid fishes are reported associating with two species of snapping shrimps (Harada, 1972). I myself confirmed 18 species of gobioid fish inhabiting burrows of snapping shrimps during the present underwater observations carried out at Nansei Islands, Shirahama and Ogasawara Islands from October 1972 to October 1974. The burrows occurred on the various sorts of sediments, from coral sand bottom in a reef lagoon to mud flat of an estuary, ranging from intertidal zone to a depth of some $40 \mathrm{~m}$.

In this paper, one new species of the genus Amblyeleotris and A. fasciata (Herre) (1953) which is recorded for the first time from Japanese waters are described. The geographical and developmental variations of Amblyeleotris japonica are also analysed, with special attention to morphological changes of pelvic fins with growth.

1) Contributions from the Seto Marine Biological Laboratory, No. 618.

Publ. Seto Mar. Biol. Lab., XXIII (1/2), 145-168, 1976.

(Article 11) 
I would like to express my sincere thanks to Dr. Douglass F. Hoese of the Australian Museum for his valuable advices on goby classification. Prof. Tamotsu Iwai of Department of Fisheries, Kyoto University has kindly informed me of literature, to whom I am indebted. Thanks are also due to Dr. William N. Eschmeyer of California Academy of Science for giving me a chance to examine some types of Herre's species. I am most grateful to Dr. Eiji Harada of our laboratory for his critical reading of the manuscript and for lending materials from Okinawa Island, and to Mr. Chuichi Araga of our laboratory for his valuable comments on the manuscript. Thanks are also due to the Marine Ecological Researching Society of Kagoshima University for lending materials from Kagoshima Bay, and to the staff of the Ogasawara Fisheries Experiment Station, who gave facilities of the use of the station.

\section{Materials and Methods}

Most of the specimens examined were collected at Nansei Islands, Shirahama, and Ogasawara Islands during the period from October 1972 to October 1974. Additional specimens of Amblyeleotris japonica from Kagoshima Bay, collected in 1972, are also compared. Nansei Islands, Shirahama, and Kagoshima Bay are directly exposed to the Kuroshio Current, while Ogasawara Islands are washed by the Kuroshio Counter Current (Fig. 1). The surface water temperatures at Shira-

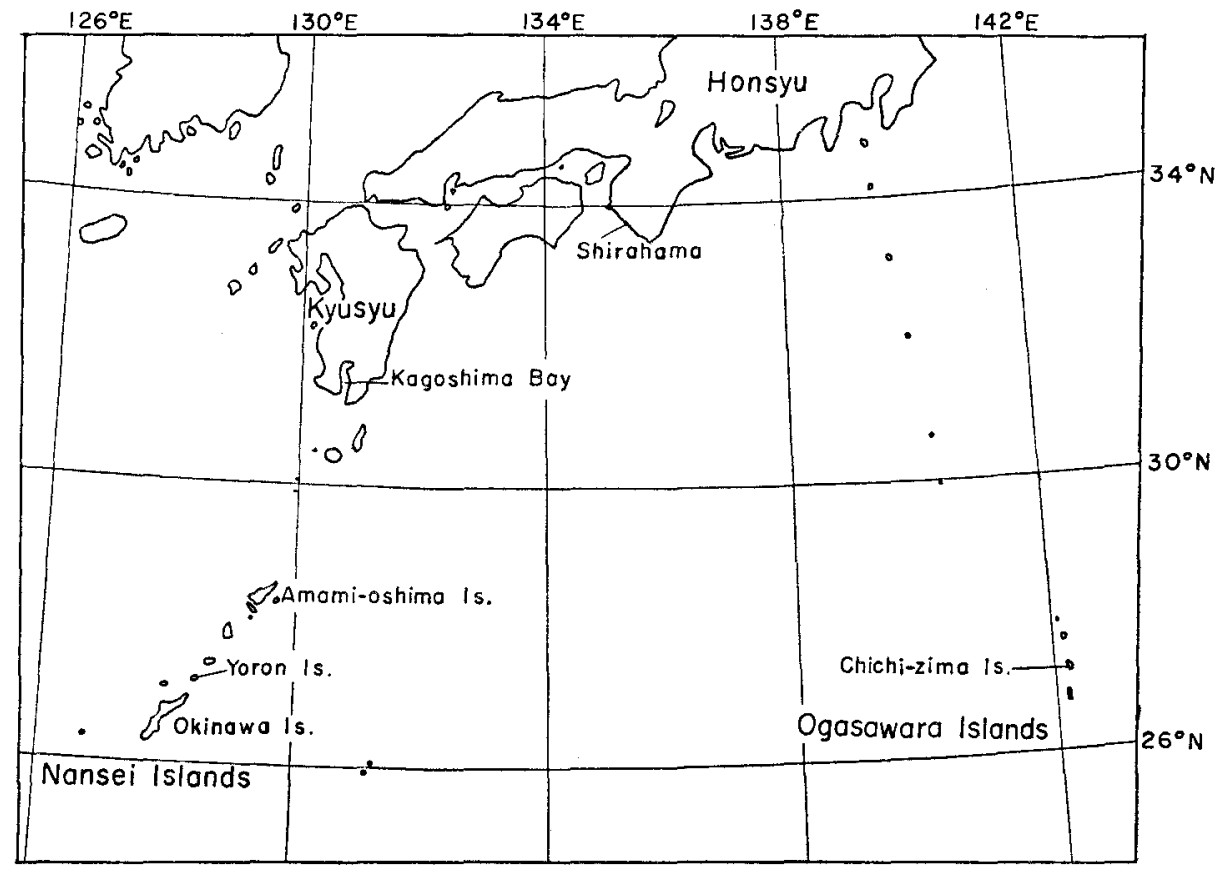

Fig. 1. Map of southern area of Japan. 
hama are about $15^{\circ} \mathrm{C}$ in winter and about $28^{\circ} \mathrm{C}$ in summer, and at Okinawa Islands they are about $5^{\circ} \mathrm{C}$ warmer in winter. The surface water of Ogasawara Islands gives temperatures subequal to that at Okinawa Islands but slightly lower in summer.

The gobioid fishes observed of the genus Amblyeleotris, as other gobioid fishes associating with the snapping shrimps are, are alert outside the burrow and quickly retreat into the burrow when a diver comes near to them. The burrows are so deep and complicate, that it is impossible to capture them by excavating the substratum, once they take refuge into the burrow. I found it the most effective way to shut the burrow near its entrance by thrusting a garden trowel into the substratum as quickly as possible after approaching to them very gently, when they were well out. Underwater angling with bait was most successful for adult gobioid fishes.

The methods of counting and measuring are as follow. The number of scales in a longitudinal series was counted from the upper edge of pectoral base to caudal base and that in a transverse series was counted from the frontal end of anal base to the middle part of second dorsal base. The length of uniting membrane of pelvic fin was measured along its median line, and the relative length of this to the longest pelvic ray (fourth ray) was calculated and designated conveniently as UM-value. All other counts and measurements were made using the standard methods of Hubbs and Lagler (1958). Measurements are expressed in thousands of standard length as proportional measurements. When the last dorsal or anal ray was branched at the base, it was counted as one ray. Gill-rakers, glossohyal bone and teeth were examined after being stained by Alizarine-red. The number of gill-rakers was counted only for the lower limb of the first gill arch, since those on the upper limb were rudimental short papillae and not regularly placed.

The specimens are deposited at the Seto Marine Biological Laboratory of Kyoto University.

\section{Descriptions of Amblyeleotris maculata n. sp. and A. fasciata (Herre)}

\section{Amblyeleotris maculata n. sp.}

(Japanese name: Dandara-datehaze)

(Fig. 2)

Holotype: SMBL Type-254, adult male, $55.5 \mathrm{~mm}$, Sesoko Island, Okinawa Island, sand and coral rubble bottom, $5 \mathrm{~m}$ depth, 21 October 1974 .

Paratypes: SMBL Type-255, adult male, $61.4 \mathrm{~mm}$, same locality and date as holotype. SMBL Type-256, young, $16.8 \mathrm{~mm}$, same locality as holotype, 23 October 1974.

\section{Description}

Counts and proportional measurements are shown in Table 1. Dorsal finrays VI-I, 12, anal fin-rays $I, 12$, pectoral fin-rays 19 or 20 ; vertebrae $10+16=26$; gill-rakers on lower limb of first arch 9 ; scales about 85 in a longitudinal series, 26 or 27 in a transverse series.

Body elongate, compressed; head obtuse, compressed slightly. Interorbital 
space very narrow, snout obtuse, as long as eye diameter; anterior nostril conical, posterior nostril without rim. Mouth oblique, jaws subequal; maxillary reaching to a vertical line through the posterior part of eye, no barbels. In upper jaw a single external series of about 15 slender caniniform teeth on each side, those in front

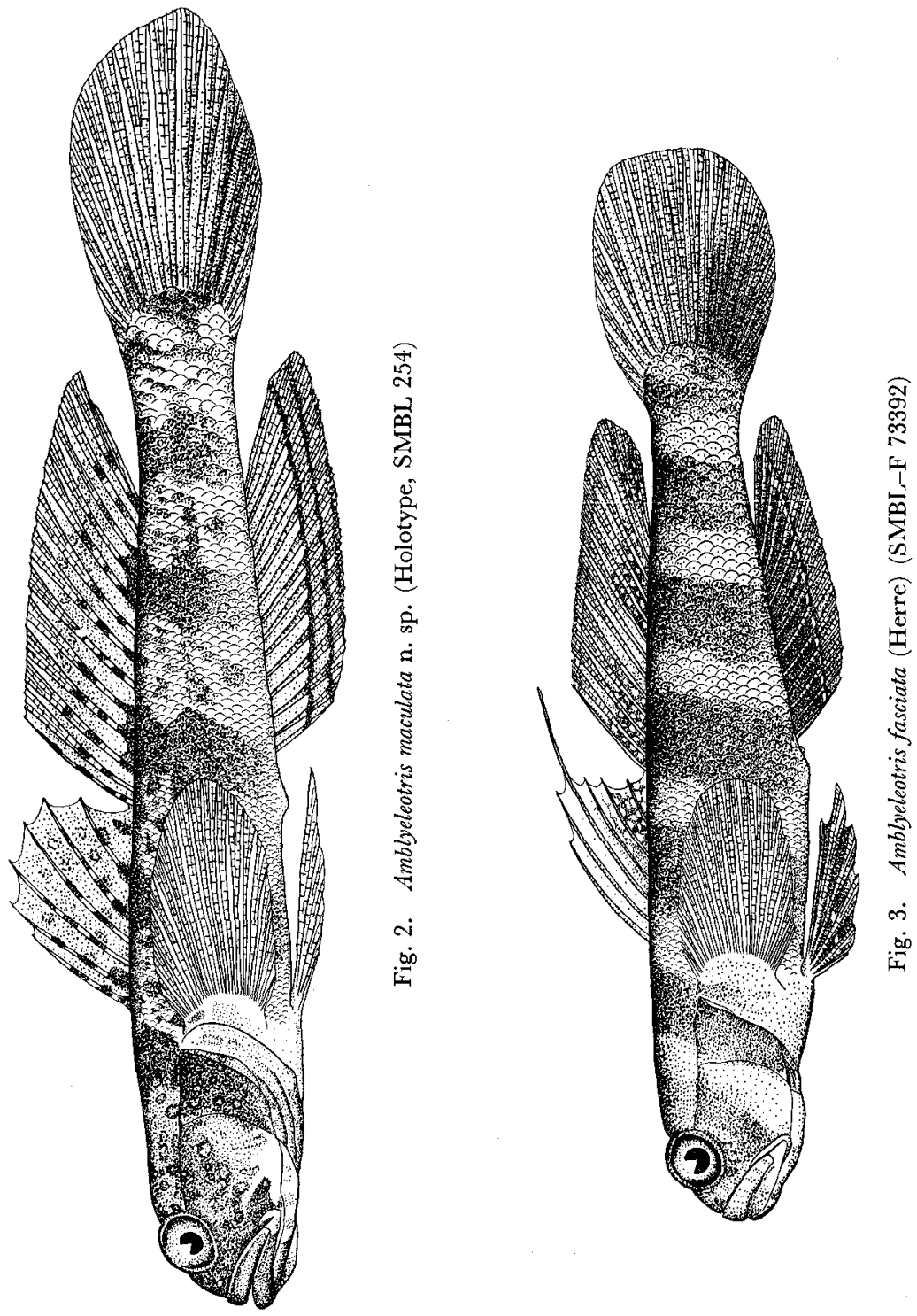

larger, and an inner band of several irregularly arranged series of small teeth. In lower jaw a cluster of villiform teeth in front, and a single series of slender teeth on each side, inside of which 1 or 2 recurved caniniform teeth. No teeth on vomer and palatines. Vomer not notably protruding downward. Tongue rounded, 
glossohyal bone narrow fan-shaped. Gill opening wide, extending to below the middle of preopercle; isthmus narrow; no fleshy flap on the inner margin of shoulder girdle. No spine on preopercle. Canal pores fully developed, sensory papillae on head poorly defined (Fig. 4).

First dorsal fin lower than body, fifth spine longest. Second dorsal fin as high as first one, the last ray branched. Anal fin subequal to second dorsal fin in height, rays becoming longer posteriorly, the last ray branched. Caudal fin oblong, its length subequal to head length. Pectoral fins without silky free rays, rounded
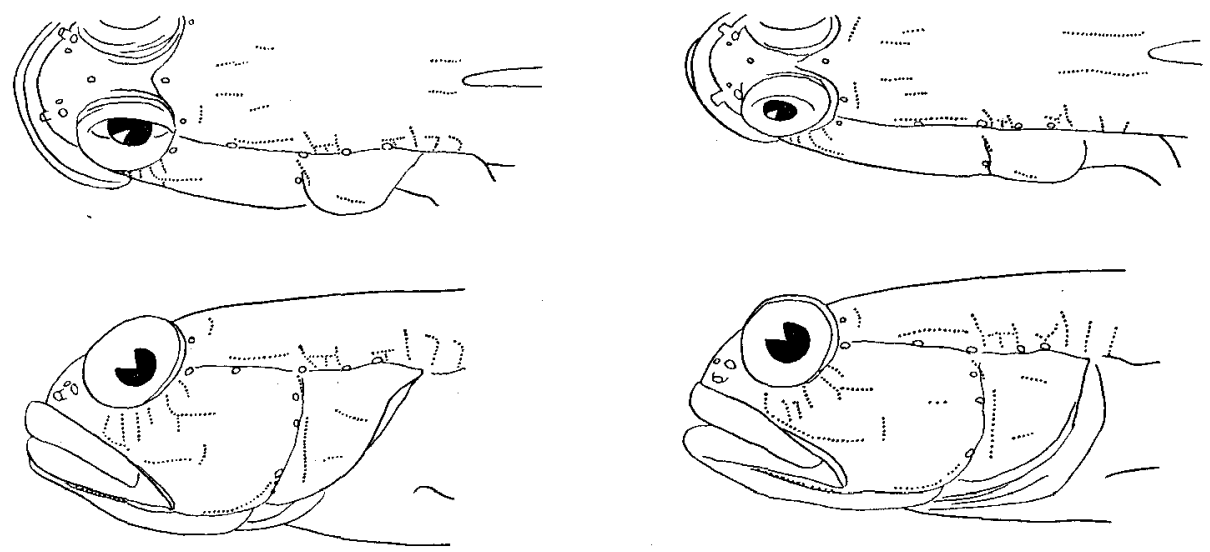

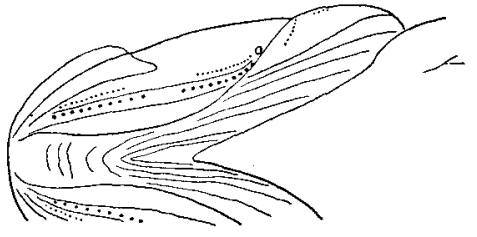

$B$

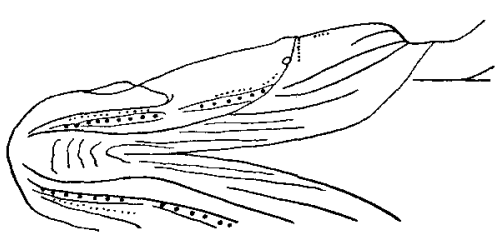

$A$

Fig. 4. Canal pores and sensory papillae. A-Amblyeleotris maculata, B-Amblyeleotris fasciata.

posteriorly, reaching to a vertical line through the origin of second dorsal fin. Pelvic fin $I, 5$, with 4 th rays longest, uniting membrane rudimentary, UM-value less than 0.15 ; pelvic frenum absent (Fig. 5).

Scales on anterior half of body small and cycloid, becoming larger and ctenoid posteriorly. Head naked, no scales on median part of nape and pectoral base. Thorax and belly scaly.

Colour of body pale yellow, with five broad transverse bands of dark brown, not sharply defined, slightly inclined forward and downward. Anteriormost band running from predorsal to opercle, second from first dorsal to pelvic fin, third and fourth from second dorsal to anal fin, fifth on caudal peduncle. Narrower band of the same colour on base of caudal fin. Some remarkable speckles scattered irregularly, the same colour as broad bands, on interspaces of broad bands. Frontal 
part of head brown, many small spots of brown or gold colour on head, a red spot on each side behind jaw. Two vermilion spots on each side of chin, throat testaceous. First and second dorsal fins semitransparent with brown spots along spines and soft rays, the distal edge of both fins pale yellow. Anal fin semitransparent or pale yellow, with whity yellow band along base of anal fin, and testaceous longitudinal band along middle of anal fin, sandwiched between narrow blue bands; distal margin blackish. Pectoral fin colourless. Membrane of pelvic fin paler orange-yellow. Caudal fin semitransparent, with an obscure brown streak at lower part.
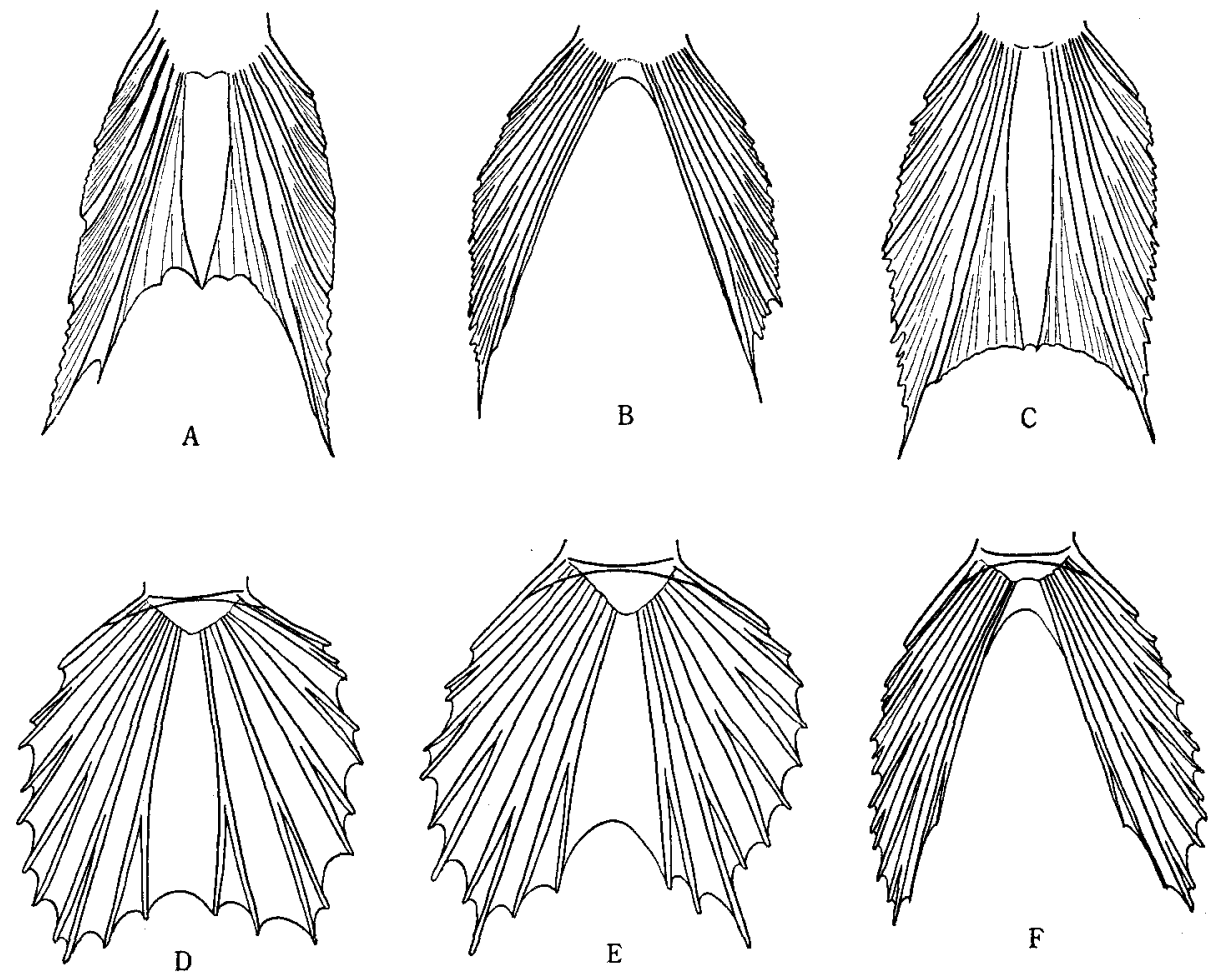

Fig. 5, The form of pelvic fins. A-Amblyeleotris fasciata, $64.7 \mathrm{~mm}$ in standard length; B-A. maculata, $55.5 \mathrm{~mm} ; \mathrm{C}$ - Type C of A. japonica, $71.6 \mathrm{~mm}$; D, E, F-Type B of A. japonica, 9.6 $\mathrm{mm}, 9.8 \mathrm{~mm}, 25.0 \mathrm{~mm}$ respectively.

\section{Amblyeleotris fasciata (Herre)}

(Japanese name: Kubiaka-haze)

(Fig. 3)

Zebreleotris fasciata Herre, 1953a, 1953b, Bikini Islands.

Specimens examined: SMBL-F 73392, adult female, $47.3 \mathrm{~mm}$, Nesebu Reef, Amami-oshima Island, sand and coral rubble bottom, $2 \mathrm{~m}$ depth, 8 November 1973; SMBL-F 73393 and 73394, adult female, $47.0 \mathrm{~mm}$, and adult females, $41.2 \mathrm{~mm}$, same locality as the former, 6 November 1973; 
SMBL-F 74021 and 74022, adult female, $52.6 \mathrm{~mm}$ and adult male, $64.7 \mathrm{~mm}$, Kominato Bay, Chichi-zima Island, Ogasawara Islands, sand and coral rubble bottom, $8 \mathrm{~m}$ depth, 7 April 1974; SMBL-F 74023 and 74024, adult female, $48.3 \mathrm{~mm}$, and adult male, $53.9 \mathrm{~mm}$, Kanameishi, Futami Bay, Chichi-zima Island, Ogasawara Islands, sand and coral rubble bottom, $10 \mathrm{~m}$ depth, 13 April 1974.

\section{Description}

Counts and proportional measurements are shown in Table 1. Dorsal fin-rays VI-I, 11 or 12; anal fin-rays I, 11 or 12; pectoral fin-rays 18 or 19; vertebrae 10 $+16=26$; gill-rakers on lower limb of first arch 9 ; scales 60 to 65 in a longitudinal series, 18 to 23 in a transverse series.

Body elongate, compressed; head obtuse, compressed slightly. Interorbital space very narrow, snout obtuse, as long as eye diameter; anterior nostril conical, posterior nostril without rim. Mouth oblique, jaws subequal; maxillary reaching to a vertical line through the posterior part of eye, no barbels. In upper jaw a single external series of about 15 slender caniniform teeth on each side, those in front larger, and an inner band of several irregularly arranged series of small teeth. In lower jaw a cluster of villiform teeth in front, and a single series of slender teeth on each side, inside of which 1 to 3 recurved caniniform teeth. No teeth on vomer and palatines. Vomer not notably protruding downward. Tongue rounded, glossohyal bone narrow fan-shaped. Gill opening wide, extending to below the middle of preopercle; isthmus narrow; no fleshy flap on the inner margin of shoulder girdle. No spine on preopercle. Canal pores fully developed, sensory papillae on head poorly defined (Fig. 4).

First dorsal fin lower than body, 3rd dorsal spine sometimes filamentous in adult. Second dorsal fin as high as first one, the last ray branched. Anal fin subequal to second dorsal fin in height, rays becoming longer posteriorly, the last ray branched. Caudal fin oblong, its length subequal to head length. Pectoral fins without silky free rays, rounded posteriorly, nearly reaching to a vertical line through the origin of second dorsal fin. Pelvic fins I, 5, with 4th rays longest, uniting membrane not fully developed, fins separated from each other at the posterior margin, UM-value 0.2 to 0.65 , pelvic frenum absent (Fig. 5).

Scales on anterior half of body small and cycloid, becoming larger and ctenoid posterioly. Head naked, more than ten small scales on median part of nape. Thorax and belly scaly. Small embedded scales on base of pectoral fin.

Colour of body pale yellow with five broad transverse bands of dark reddish purple, slightly inclined forward and downward; anteriormost band running from predorsal to opercle, second from first dorsal to pelvic fin, third and fourth from second dorsal to anal fin, fifth on caudal peduncle; these bands obviously broader than interspace. Narrower band of the same colour on base of caudal fin. From occipital region to posterior part of upper jaw reddish brown. Nape and cheek scattered with many orange-red spots; a part of throat red. Dorsal spines and soft rays yellow, membrane of posterior half of first dorsal fin and whole second dorsal fin yellow with small orange-red spots. Basal half of anal fin dark brown, with 
Table 1. Counts and proportional measurements of Amblyeleotris maculata and A. fasciata.

\begin{tabular}{|c|c|c|c|c|c|c|c|c|c|c|}
\hline & \multicolumn{3}{|c|}{ Amblyeleotris maculata } & \multicolumn{5}{|c|}{ Amblyeleotris fasciata } & \multirow[b]{2}{*}{$\begin{array}{l}\text { SMBL- } \\
\text { F74023 }\end{array}$} & \multirow[b]{2}{*}{$\begin{array}{l}\text { SMBL- } \\
\text { F74024 }\end{array}$} \\
\hline & $\begin{array}{l}\text { SMBL 254 } \\
\text { (holotype) }\end{array}$ & SMBL 255 & SMBL 256 & $\begin{array}{l}\text { SMBL- } \\
\text { F73392 }\end{array}$ & $\begin{array}{l}\text { SMBL- } \\
\text { F73393 }\end{array}$ & $\begin{array}{l}\text { SMBL- } \\
\text { F73394 }\end{array}$ & $\begin{array}{l}\text { SMBL- } \\
\text { F74021 }\end{array}$ & $\begin{array}{l}\text { SMBL- } \\
\text { F74022 }\end{array}$ & & \\
\hline Sex & $\$$ & 战 & - & 우 & 우 & 오 & 오 & $\hat{o}$ & 우 & 占 \\
\hline Standard length $(\mathrm{mm})$ & 55.5 & 61.4 & 16.8 & 47.3 & 47.0 & 41.2 & 52.6 & 64.7 & 48.3 & 53.9 \\
\hline Dorsal fin rays & VI-I, 12 & VI-I, 12 & VI-I, 12 & VI-I, 12 & VI-I, 11 & VI-I, 12 & VI-I, 12 & VI-I,12 & VI-I, 12 & VI-I, 12 \\
\hline Anal fin rays & $\mathrm{I}, 12$ & $\mathbf{I}, 12$ & I, 12 & I, 12 & I, 12 & $\mathrm{I}, 12$ & I, 12 & $\mathrm{I}, 12$ & I, 12 & $\mathrm{I}, \mathrm{12}$ \\
\hline Pectoral fin rays (both sides) & $19-19$ & $20-19$ & $19-19$ & $18-18$ & $18-18$ & $18-18$ & $18-19$ & $19-19$ & $19-19$ & $18-18$ \\
\hline Scales in longitudinal series & 83 & 84 & - & 61 & 60 & 60 & 62 & 63 & 65 & 62 \\
\hline Scales in transverse series & 26 & 27 & - & 18 & 18 & 18 & 21 & 22 & 23 & 21 \\
\hline Total length & 1330 & 1360 & 1290 & 1280 & 1310 & 1350 & 1270 & 1300 & 1260 & 1280 \\
\hline Body height & 173 & 189 & 185 & 207 & 213 & 226 & 203 & 192 & 203 & 197 \\
\hline Head length & 278 & 272 & 304 & 281 & 309 & 321 & 285 & 292 & 288 & 308 \\
\hline Eye diameter & 68 & 70 & 101 & 72 & 77 & 73 & 70 & 66 & 76 & 78 \\
\hline Interorbital width & 16 & 16 & 9 & 23 & 23 & 29 & 15 & 15 & 21 & 20 \\
\hline Snout length & 65 & 67 & 65 & 66 & 72 & 75 & 80 & 73 & 66 & 67 \\
\hline Caudal peduncle length & 178 & 171 & 173 & 186 & 162 & 180 & 183 & 193 & 184 & 184 \\
\hline Caudal peduncle height & 105 & 103 & 83 & 110 & 111 & 124 & 116 & 116 & 108 & 111 \\
\hline First dorsal fin length & 151 & 204 & 137 & 294 & 223 & 287 & 171 & 283 & 147 & 167 \\
\hline Second dorsal fin length & 191 & 189 & 165 & 192 & 194 & 192 & 171 & 187 & 162 & 175 \\
\hline Second dorsal fin base & 305 & 299 & 263 & 273 & 275 & 279 & 285 & 293 & 283 & 295 \\
\hline Anal fin length & 197 & 192 & 137 & 182 & 198 & 206 & 177 & 213 & 153 & 176 \\
\hline Anal fin base & 261 & 264 & 226 & 233 & 234 & 253 & 249 & 253 & 236 & 262 \\
\hline Pectoral fin length & 270 & 272 & 298 & 258 & 281 & 284 & 279 & 248 & 248 & 279 \\
\hline Pelvic fin length & 272 & 257 & 256 & 237 & 238 & 264 & 222 & 240 & 232 & 223 \\
\hline Predorsal length & 326 & 315 & 369 & 357 & 343 & 364 & 359 & 331 & 347 & 351 \\
\hline Pre-second dorsal lenth & 541 & 532 & 565 & 545 & 549 & 570 & 553 & 513 & 541 & 546 \\
\hline Prepelvic length & 301 & 305 & 316 & 313 & 381 & 369 & 327 & 340 & 313 & 332 \\
\hline Preanal length & 571 & 568 & 595 & 584 & 594 & 595 & 581 & 578 & 578 & 578 \\
\hline
\end{tabular}


blue spots bordered with cobalt blue; along middle of anal fin two narrow stripes, lower orangered and upper blue; distal half of anal fin yellow. Pectoral fin almost colourless. Membrane of pelvic fin dark brown, blue longitudinal lines at part and between basal 5 th ray and spine, four blue spots bordered with dark blue on uniting membrane. Caudal fin transparent near distal edge; lower part of basal half dark brown, with blue lines and spots; an orange-red spot at upper quarter of caudal base. Remarks

The genus Zebreleotris Herre (1953) is undoubtly a synonym of Amblyeleotris because of the following reasons.

More than ten genera, one of which is Zebreleotris, were newly established by Herre by reason of having a pair of incisor teeth on vomer (Herre, 1943, 1945, 1953a). Out of these Herre's genera, I had a chance to examine the paratypes of Smilogobius singapurensis and Mars caeruleomaculatus. It became clear after examination that a pair of incisor on vomer stated by Herre in these two species do mean a pair of beak-like vomerine protuberances which can not be regarded as the true teeth. Consequently, it is definite that Herre's concept about vomerine teeth must indicate, in fact, vomerine protuberances and "two vomerine teeth to form a low transverse ridge" in Zebreleotris are nothing but short protuberances. The same protuberances, which also exist, more or less, among some groups of Gobiidae, are present in $\mathrm{Am}$ blyeleotris. Moreover, Zebreleotris and Amblyeleotris have following characters in common: scales in longitudinal series about 60 to 70 ; interorbital space very narrow and eye high up; gill opening wide; snout shorter than (or as long as) eye diameter.

The species in question from Nansei Islands and Ogasawara Islands is close to Amblyeleotris fasciata (Herre) described on two specimens from Bikini Island in body colouration and having cycloid scales of the median part of nape, pectoral base and prepelvic in common, though there are several differences, which are not trifle, between them: second dorsal soft rays 12 or 11 (13); pelvic soft rays 5 (4?); eye in head 3.8 to $4.4(3.3)$. In this study, I provisionally regard the species in question as $A$. fascata, following the opinion of Dr. Hoese who is extensively studying the taxonomy of the gobioid fishes, especially Cryptocentrus and its related genera (personal communication). The further studies about this species are necessary.

\section{Geographical Variations of Amblyeleotris japonica Takagi}

Amblyeleotris japonica was first reported from Kagoshima Bay by Takagi (1957), and was later recorded from the coastal waters of Boso Peninsula, Izu Peninsula, Kii Peninsula, Amakusa Island and Nansei Islands by various authors. In the course of the present study, I found that this species also occurred in Ogasawara Islands, as well as at various additional localities of Nansei Islands. In Ogasawara Islands 8 individuals from $25.0 \mathrm{~mm}$ to $71.6 \mathrm{~mm}$ in standard length were collected at Kanameishi and Eboshiiwa in Futami Bay, Chichi-zima Island. In Nansei Islands 24 individuals from $11.0 \mathrm{~mm}$ to $53.9 \mathrm{~mm}$ in standard length were collected at following localities: Akasaki Reef, Yoron Island; Oh-zima, Okinawa Island: Miyagi-zima, 
Table 2. Number of soft rays and scales in

\begin{tabular}{|c|c|c|c|c|c|c|c|c|c|c|}
\hline & \multicolumn{4}{|c|}{ Second dorsal soft rays } & \multicolumn{3}{|c|}{ Anal soft rays } & \multicolumn{3}{|c|}{ Pectoral rays } \\
\hline & 11 & 12 & 13 & 14 & 12 & 13 & 14 & 18 & 19 & 20 \\
\hline \multicolumn{11}{|l|}{ Amblyeleotris japonica } \\
\hline Nansei Is. & 2 & 15 & & & 17 & & & 4 & 20 & 10 \\
\hline Shirahama & & 2 & 16 & & & 4 & 14 & 14 & 17 & 3 \\
\hline Kagoshima & & & 2 & 1 & & 1 & 2 & 6 & & \\
\hline Ogasawara Is. & & & 7 & 1 & & 7 & 1 & 2 & 11 & 3 \\
\hline \multicolumn{11}{|l|}{ Amblyeleotris maculata } \\
\hline Nansei Is. & & 3 & & & 3 & & & & 5 & 1 \\
\hline \multicolumn{11}{|l|}{ Amblyeleotris fasciata } \\
\hline Nansei Is. & 2 & 3 & & & 5 & & & 9 & 1 & \\
\hline Ogasawara Is. & & 5 & & & 5 & & & 3 & 7 & \\
\hline
\end{tabular}

Okinawa Island; Yomitani, Okinawa Island; Sesoko Island, Okinawa Island. More than half of the specimens are the collections from Sesoko Island. Further, more than 50 individuals from $8.1 \mathrm{~mm}$ to $82.9 \mathrm{~mm}$ in standard length were caught in the northern coast of Rinkai and Hatake-zima Island in Shirahama.

All individuals of $A$. japonica observed in these three geographical areas occurred on the sandy bottom with scattered shell fragments and coral rubble and were in association with the snapping shrimps, such as Alpheus bellulus or other alpheid shrimps. No distinct differences in habitat and behaviour were recognized among the populations in the three localities. Their colour was milky white with five broad transverse bands of dark brown between predorsal and caudal peduncle, and a speckle of the same colour on caudal base. However, I noticed, after quick examination of the animals collected, that there were some remarkable differences in the proportional features and colouration among the three populations. These specimens were rendered for closer examination and comparison, together with three specimens from Okikozima Island in Kagoshima Bay, collected on 5 September 1972, which I had a chance to examine. For convenience' sake the specimens from Nansei Islands, Shirahama and Ogasawara Islands are indicated as Type A, Type B and Type C respectively.

Counts and proportional measurements of these three groups of $A$. japonica, together with that of $A$. maculata and $A$. fasciata, are shown in Table 2 and Table 3. Maximum, minimum and average values of proportional measurements are given for each group of specimens. Since the relative sizes of some characters vary with body size or age, it is not appropriate to compare the proportional measurements without taking into account body size or age. Thus, youngs and adults were measured for detailed comparison, namely, 17 specimens from Type A, 18 from Type B and 8 from Type C. Juveniles, less than about $15 \mathrm{~mm}$ in standard length, were rendered only for the examinations of the changes of the form of pelvic fins. 
three species of Amblyeleotris.

\begin{tabular}{|c|c|c|c|c|c|c|c|c|c|c|c|}
\hline \multicolumn{8}{|c|}{ Scales in longitudinal series } & \multicolumn{4}{|c|}{ Scales in transverse series } \\
\hline \multirow[t]{5}{*}{-60} & -65 & -70 & -75 & -80 & -85 & -90 & -95 & -19 & -22 & -25 & -28 \\
\hline & 2 & 7 & 7 & 1 & & & & 4 & 13 & & \\
\hline & & & 2 & 7 & 4 & 3 & & & 11 & 5 & \\
\hline & & & & 1 & 2 & & & & 3 & & \\
\hline & & & & & 5 & 2 & 1 & & & 2 & 6 \\
\hline & & & & & 2 & & & & & & 2 \\
\hline 3 & 1 & & & & & & & 4 & & & \\
\hline & 3 & 1 & & & & & & & 3 & 1 & \\
\hline
\end{tabular}

The relations between each proportional measurement and standard length are shown in Figure 6 to 8 .

In all three types, as well as in other two species, as also shown in Figures 6 to 8 , the ratios of total length, caudal peduncle height, first and second dorsal, and anal fin length, and second dorsal and anal fin bases increase with body size. On the contrary, those of head length, eye diameter, pectoral fin length, predorsal, presecond dorsal and preanal length decrease as the animals grow. Increase or decrease of the ratios of body height and pelvic fin length with growth is not clear.

General characters of three types of $A$. japonica are as follow. Type A (Nansei Islands)

Dorsal fin-rays VI-I, 11 or 12; anal fin-rays I, 12; pectoral fin-rays 18 to 20; vertebrae $10+16=26$; gill-rakers on lower limb of first arch 8 or 9 ; scales 65 to 77 in a longitudinal series, 19 to 22 in a transverse series. Fourth or third spine longest in first dorsal spines. UM-value 0.06 to 0.28 , pelvic frenum absent (Fig. 9). Median part of nape no scales, pectoral base also scaleless except in rare cases. Thorax scaly in specimens of more than $40 \mathrm{~mm}$ in standard length.

Colour of body creamy white with five broad transverse bands of dark brown from predorsal to caudal peduncle; these bands narrower than (or as broad as) interspace. A narrow band and a speckle of the same colour below eye and at caudal base respectively. Cheek and pectoral base with small pale blue spots, jugular region pale brown. First and second dorsal fin semitransparent, with pale yellow spots and streaks. Anal fin pale yellow, basal part whitish, along middle of anal fin a testaceous streak sandwiched in between two pale blue stripes, distal half dark. Pectoral fin colourless, pelvic fin with irregular yellow bands. Membrane of caudal fin pale yellow, with a brown streak at lower part.

Type B (Shirahama)

Dorsal fin-rays VI-I, 12 or 13; anal fin-rays I, 13 or 14; pectoral fin-rays 18 
Table 3. Maximum, minimum and average values of proportional measurements, and presence $(+)$ or absence $(-)$ of scales on median part of nape and pectoral base, and pelvic frenum in three species of Amblyeleotris.

\begin{tabular}{|c|c|c|c|c|c|c|c|}
\hline \multirow[b]{2}{*}{ Locality } & \multicolumn{4}{|c|}{ Amblyeleotris japonica } & \multirow{2}{*}{$\overbrace{\text { Nansei Is. }}^{\text {Amblyeleotris maculata }}$} & \multicolumn{2}{|c|}{ Amblyeleotris fasciata } \\
\hline & Nansei Is. & Shirahama & Kagoshima & Ogasawara Is. & & Nansei Is. & Ogasawara Is. \\
\hline Number of specimens & 17 & 18 & 3 & 8 & 3 & 5 & 5 \\
\hline $\operatorname{Sex}(q+\hat{q})$ & $7+9$ & $8+8$ & $1+2$ & $4+3$ & $0+2$ & $2+2$ & $3+0$ \\
\hline Standard length $(\mathrm{mm})$ & $18.2-53.9(35.1)$ & $18.8-82.9(48.8)$ & $66.1-75.2(70.7)$ & $25.0-71.6(52.2)$ & $16.8-61.4(44.6)$ & $15.5-47.3(35.4)$ & $24.0-64.8(48.7)$ \\
\hline Total length & $1280-1360(1300)$ & $1290-1410(1360)$ & $1410-1460(1440)$ & $1280-1390(1350)$ & $1290-1360(1330)$ & $1270-1350(1310)$ & $1260-1300(1270)$ \\
\hline Body height & $182-205(198)$ & $161-182(172)$ & $174-182(177)$ & $171-191(179)$ & $173-189(182)$ & $196-226(207)$ & $192-203(197)$ \\
\hline Head length & $276-337(308)$ & $242-292(270)$ & $243-260(253)$ & $237-286(268)$ & $272-304(285)$ & $281-348(311)$ & $285-308(295)$ \\
\hline Eye diameter & $66-104(81)$ & $59-96(\quad 72)$ & $58-65(61)$ & $59-88(72)$ & $68-101(75)$ & $72-97(80)$ & $66-83(75)$ \\
\hline Intero & $7-\quad 33(16)$ & $5-20(14)$ & $24-\quad 26(\quad 25)$ & $8-23(15)$ & $9-\quad 16(14)$ & $10-29(19)$ & $15-\quad 21(18)$ \\
\hline Snou & $49-\quad 92(\quad 68)$ & $52-76(60)$ & $56-\quad 59(\quad 57)$ & $63-74(\quad 67)$ & $65-67(66)$ & $54-\quad 75(\quad 67)$ & $63-80(70)$ \\
\hline length & $151-172(162)$ & $130-165(148)$ & $153-159(156)$ & $134-218(159)$ & $171-178(174)$ & $162-200(183)$ & $171-193(183)$ \\
\hline leight & $97-120(110)$ & $89-107(98)$ & $97-103(101)$ & $92-108(102)$ & $83-105(97)$ & $104-124(111)$ & $100-116(110)$ \\
\hline First & $126-232(181)$ & $137-336(197)$ & $238-293(258)$ & $141-199(183)$ & $137-204(164)$ & $154-194(186)$ & $142-283(182)$ \\
\hline ngth & $154-260(188)$ & $129-290(183)$ & $218-246(230)$ & $144-226(189)$ & $165-191(182)$ & $161-294(228)$ & $150-187(169)$ \\
\hline Sec & $258-311(279)$ & $288-338(323)$ & $316-346(329)$ & $291-342(319)$ & $263-342(289)$ & $246-279(266)$ & $267-295(285)$ \\
\hline An & $154-239(182)$ & $136-227(175)$ & $212-224(218)$ & $140-198(181)$ & $137-197(175)$ & $158-206(185)$ & $150-213(174)$ \\
\hline Anaf fin base & $226-274(249)$ & $253-332(298)$ & $295-318(309)$ & $276-317(298)$ & $226-264(248)$ & $231-258(242)$ & $236-262(250)$ \\
\hline Pectoral fin length & $251-336(297)$ & $228-309(266)$ & $247-266(260)$ & $235-290(267)$ & $270-298(280)$ & $237-284(257)$ & $248-279(266)$ \\
\hline Pelvic fin length & $263-299(281)$ & $232-302(259)$ & $265-284(274)$ & $220-265(244)$ & $256-272(262)$ & $258-336(286)$ & $222-250(233)$ \\
\hline Predorsal length & $333-385(358)$ & $300-372(323)$ & $311-318(315)$ & $323-357(340)$ & $315-369(337)$ & $343-400(364)$ & $331-366(351)$ \\
\hline Presecond dorsal length & $541-581(557)$ & $505-565(523)$ & $504-516(510)$ & $525-550(538)$ & $532-565(546)$ & $545-581(560)$ & $513-556(542)$ \\
\hline Prepelvic length & $334-407(357)$ & $301-357(327)$ & $313-322(316)$ & $302-339(317)$ & $301-316(307)$ & $313-380(352)$ & $313-340(328)$ \\
\hline Preanal length & $559-614(590)$ & $532-592(564)$ & $545-572(563)$ & $553-575(562)$ & $568-595(578)$ & $584-613(594)$ & $559-581(575)$ \\
\hline $\begin{array}{l}\text { Scales on mediar } \\
\text { of nape }\end{array}$ & - & $+($ or -$)$ & $+($ or -$)$ & - & - & + & + \\
\hline Scales on pectoral base & - & - & - & - & - & + & + \\
\hline Pelvic frenum & - & + & + & - & - & - & - \\
\hline
\end{tabular}




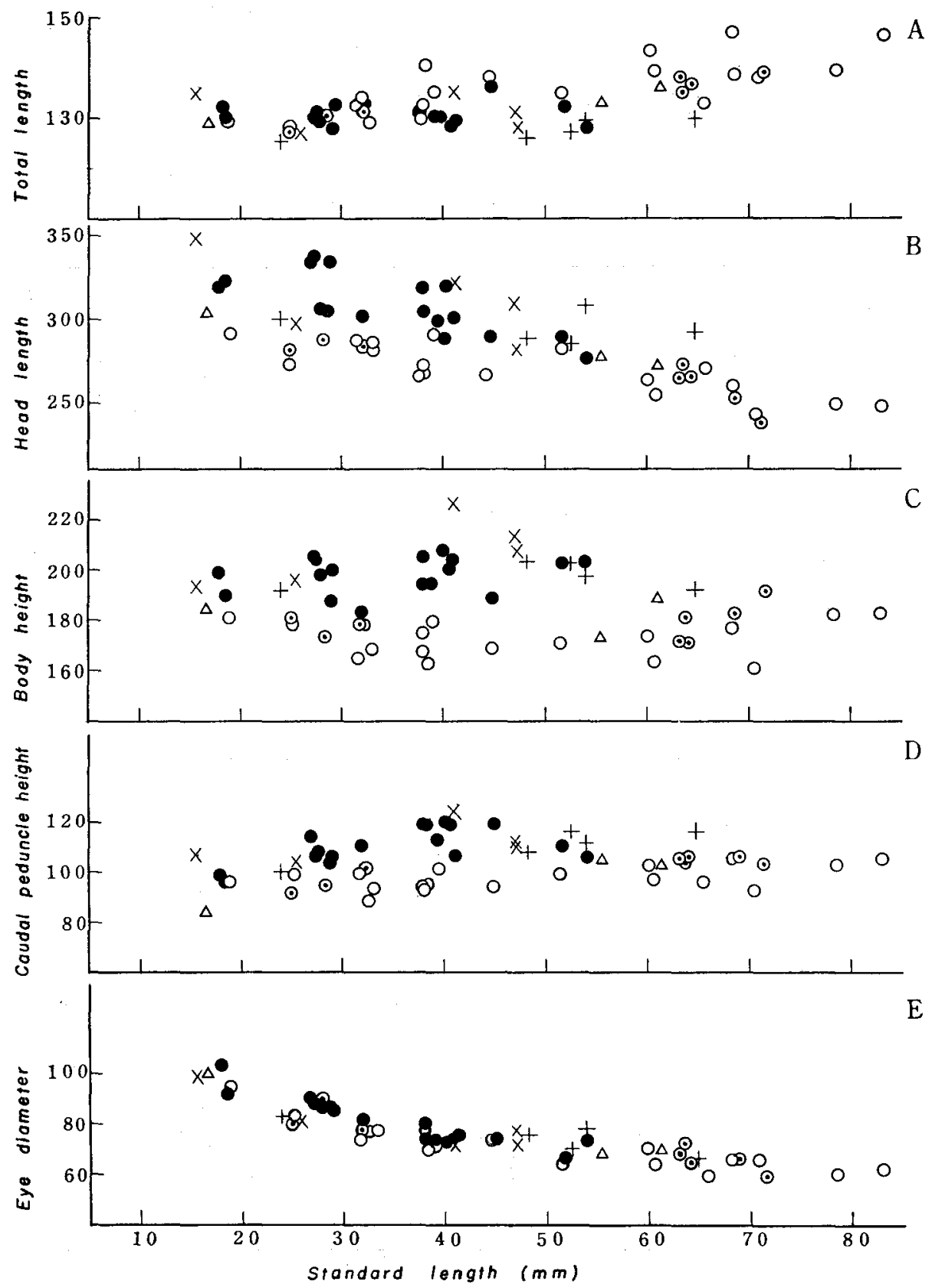

Fig. 6. The relations between each proportional measurement and standard length in three species of Amblyeleotris. A-Total length, B-Head length, C-Body height, D-Caudal peduncle height, E-Eye diameter.

-Type A of Amblyeleotris japonica, O-Type B of A. japonica, ○-Type C of A. japonica, $\triangle-A$. maculata, $\times-A$. fasciata in Nansei Islands, $+-A$. fasciata in Ogasawara Islands. 


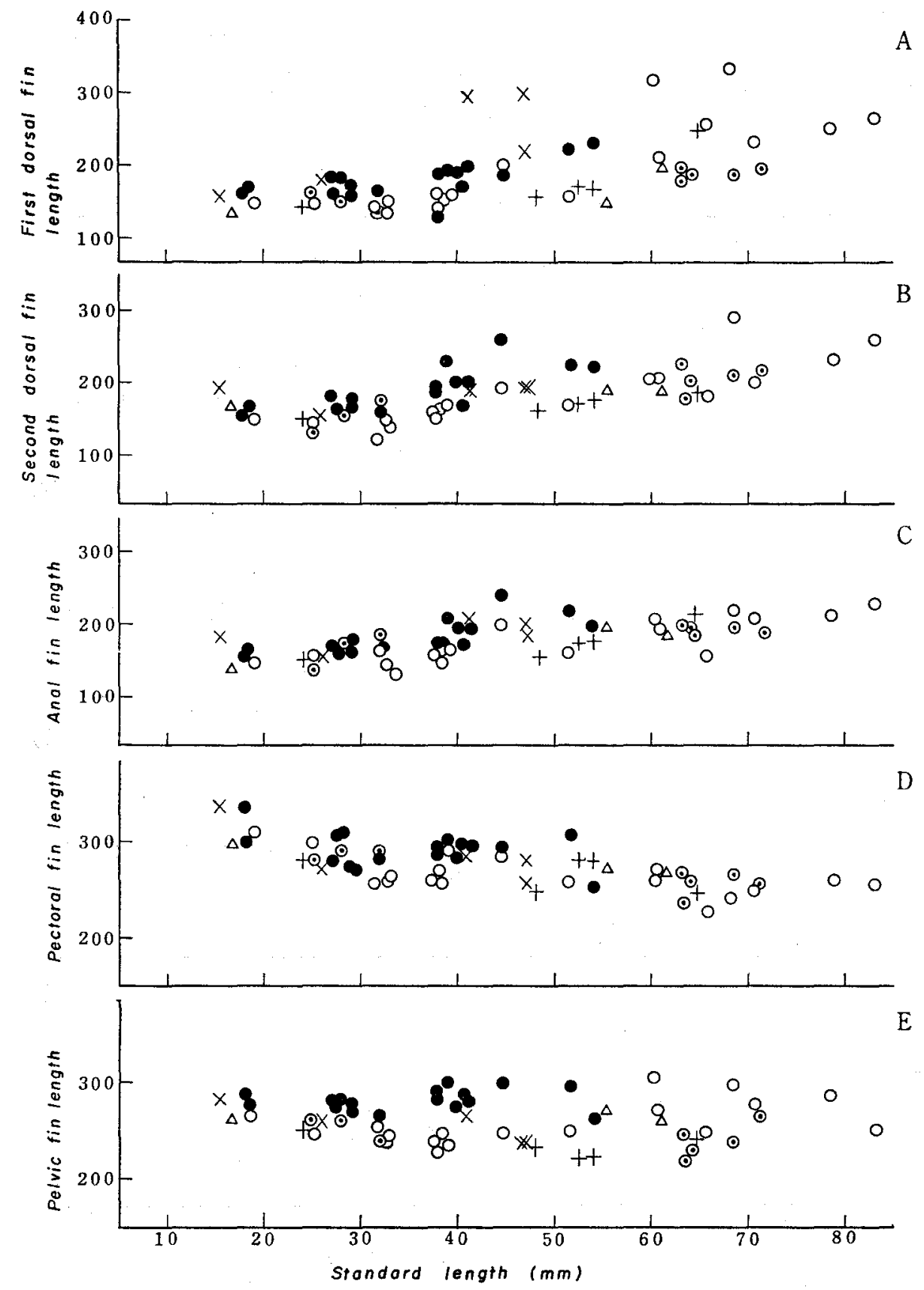

Fig. 7. The relations between each proportional measurement and standard length in three species of Amblyeleotris.

A-First dorsal fin length, B-Second dorsal fin length, $\mathrm{C}$ - Anal fin length, D-Pectoral fin length, $\mathbf{E}-$ Pelvic fin length. Marks are same as in Fig. 6. 


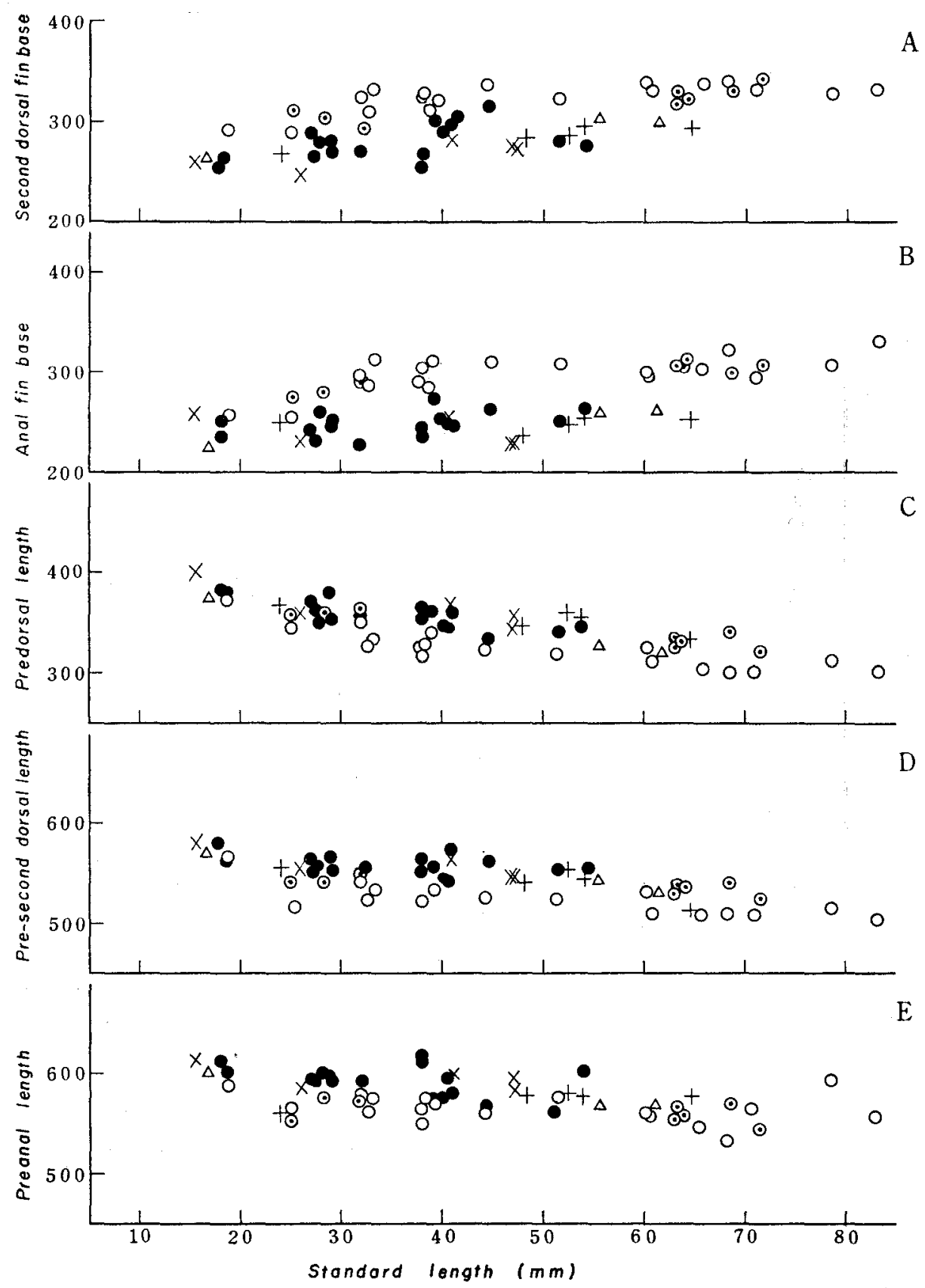

Fig. 8. The relations between each proportional measurement and standard length in three species of Amblyeleotris.

A-Second dorsal fin base, B-Anal fin base, C-Predorsal length, D-Pre-second dorsal length, E-Preanal length. Marks are same as in Fig. 6. 
to 20 ; vertebrae $10+16=26$ (very rarely $10+15=25$ ); gill-rakers on lower limb of first arch 8 to 10 ; scales 74 to 87 in a longitudinal series, 21 to 24 in a transverse series. Third spine longest in first dorsal spines. Short pelvic frenum present. The form of pelvic fins drastically changes with growth (Fig. 9). Uniting membrane of juvenile about $10 \mathrm{~mm}$ in standard length is fully developing and UM-value is 0.7 to 0.85 ; the form is disk-like. In the specimens growing up more than about $12 \mathrm{~mm}$, uniting membrane reduces suddenly, and pelvic fins are connected only at their bases with vestigial membrane. On median part of nape about ten embedded scales present, but sometimes absent. Pectoral base scaleless except in rare cases. Thorax scaly in specimens more than $32 \mathrm{~mm}$ in standard length. Colour of body creamy

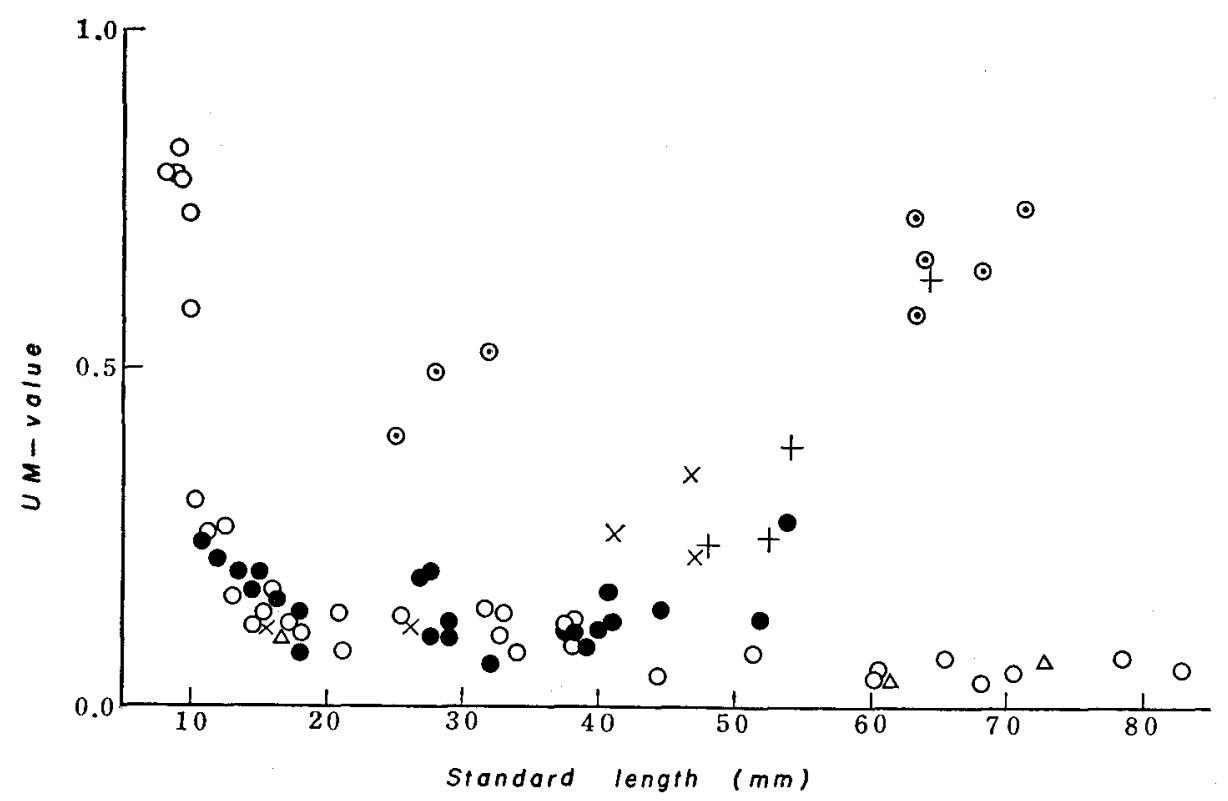

Fig. 9. The relations between UM-value and standard length in three species of Amblyeleotris. Marks are same as in Fig. 6.

white or pale yellow, with five broad transverse bands of dark brown from predorsal to caudal peduncle; these bands narrower than (or as broad as) interspace. Some part of chin and jugular region dark brown. On area of just behind jaw edge and at base of caudal fin a spot of the same colour respectively. Short spots and streaks of pale blue-purple on head and pectoral base. First and second dorsal fins pale yellow with many spots of pale blue-purple, a narrower stripe of orange at lower quater. Basal part of anal fin pale yellow with spots of pale blue-purple, a dark brown streak along middle part, distal half of anal fin dusky. Pectoral fin colourless. Pelvic rays yellow or orange, membrane blue. Caudal fin semitransparent or pale yellow, with dark brown stripes at lower part and spots and streaks of pale blue-purple at distal part. 
The specimens collected at Kagoshima Bay are similar to Type B in most features, with slight difference or deviation in some characters: dorsal fin-rays VI-I, 13 or 14; anal fin-rays I, 13 or 14; pectoral fin-rays 18; scales 82 to 85 in a longitudinal series, 20 to 22 in a transverse series. Colour in life not known.

Type C (Ogasawara Islands)

Dorsal fin-rays VI-I, 13 or 14; anal fin-rays I, 13 or 14; pectoral fin-rays 18 to 20 ; vertebrae $10+16=26$; gill-rakers on lower limb of first arch 10 ; scales 81 to 94 in a longitudinal series, 25 to 28 in a transverse series. Fourth spine longest in first dorsal spines. UM-value 0.40 to 0.74 , pelvic frenum absent (Fig. 9). Median part of nape and pectoral base without scales. Thorax scaly in adult.

Colour of body creamy white or pale yellow with five broad bands of dark brown from predorsal to caudal pcduncle, second to fourth bands having short con-
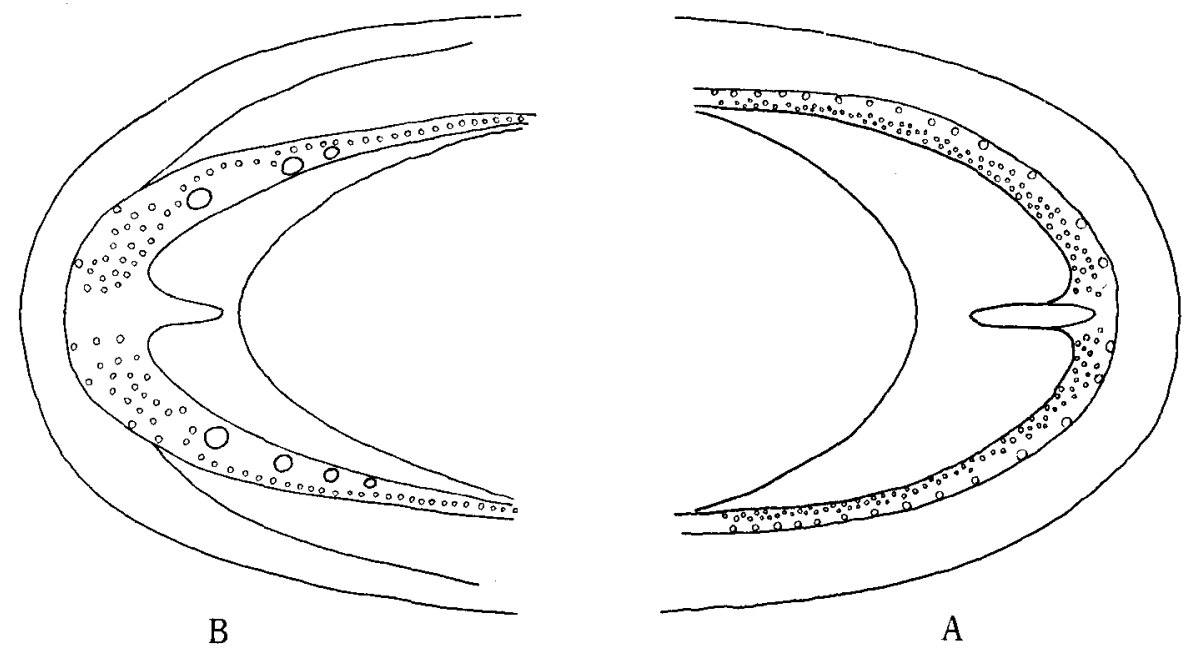

Fig. 10. Diagrammatic teeth arrangement in upper jaw (A) and lower jaw (B) of Type B of Amblyeleotris japonica, which is essentially common to three species of Amblyeleotris in Japan.

tinuations into basal part of dorsal and anal fins; these bands narrower than (or as broad as) interspace. A narrow band and a speckle of the same colour below eye and at caudal base respectively. Head and pectoral base scattered with many blue-purple spots. A deep red spot just behind each jaw which can be seen only when mouth is opened. First dorsal fin pale blue at basal half, and semitransparent or faint yellow at distal half, each spots and vermiculated specks of yellow or orange. Second dorsal fin semitransparent or pale yellow with a longitudinal streak and spots of blue at basal part. Anal fin pale yellow at basal half, and pale brown at distal edge, along middle of anal fin a dark brown stripe. Pectoral fin colourless. Pelvic fin faint brown at basal half, and pale yellow at distal half; irregular pale blue streaks along the ray. Caudal fin semitransparent or pale yellow, with a brown streak along rays and indistinct spots of blue-purple at basal part. 
Three types of $A$. japonica have following characters in common. Interorbital space very narrow; in upper jaw a single external series of about 15 slender caniniform teeth on each side, those in front larger, and an inner band of several irregularly arranged series of small teeth; in lower jaw a cluster of villiform teeth in front, and a single series of slender teeth on each side, inside of which 1 to 4 recureved caniniform teeth (Fig. 10); tongue rounded, glossohyal bone narrow fan-shaped; gill opening wide, extending to below the middle of preopercle; isthmus narrow; canal pores fully developed, sensory papillae on head poorly defined. However, three types can be easily distinguished with one another by fin formula, number of scales, proportional characters, the form of pelvic fins, presence or absence of scales on median part of nape and pectoral base, adult size and colouration.

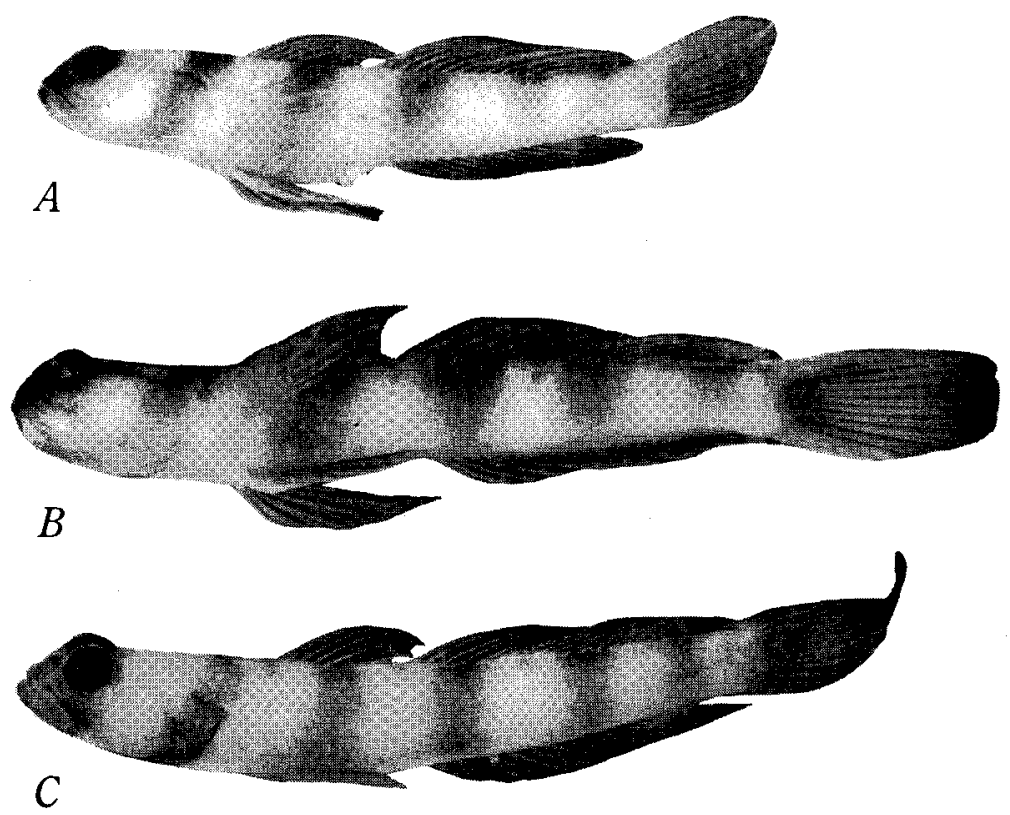

Fig. 11. Specimens of Type A (A), Type B (B) and Type C (C) of Amblyeleotris japonica. Natural size.

As shown in Table 2, each of three types has the peculiar number of second dorsal and anal soft rays: 12 (rarely 11) and 12 in Type A, 13 (rarely 12) and 14 (rarely 13) in Type B, and 13 (rarely 14) and 13 (rarely 14) in Type C. Although there are wide ranges of variation in the number of longitudinal scales, about 15 to 20 , in all three types, which overlap each other, differences in average number are distinct and 70, 80 and 86 are recorded for Type A, Type B and Type C respectively.

The differences of proportional features among three types are also remarkable (Figs. 6 to 8). The ratios of head length, body height, caudal peduncle height, pelvic length, pectoral length, lengths of predorsal, pre-second dorsal and preanal are obviously largest in Type A, but are subequal between Type B and Type C. 
On the other hand, Type $\mathrm{A}$ is smallest in the ratios of total body length and lengths of second dorsal and anal base, while these ratios are largest in Type B. There are no distinct differences in the ratios of lengths of first and second dorsal and anal fins. The longest spine of first dorsal fin is third or fourth in Type A, third in Type B and fourth in Type $\mathrm{C}$. There is no variation in the ratio of eye diameter.

Presense of pelvic frenum is characteristic in Type B, but it is absent in other two types. Uniting membrane in adult develops best in Type $\mathrm{C}$ among three types, and the form of pelvic fins resembles that of Callogobius hasselti (Bleeker). Uniting membrane of Type $\mathrm{A}$ is short, but it has a tendency to enlarge as the animal grows, as in Type C. Uniting membrane of the adult of Type B is rudimentary, though it is developed fully in the early juvenile.

Type $\mathrm{A}$ and Type $\mathrm{C}$ are without scales on median part of nape except in rare cases, while more than half of Type B have embedded scales. All types have no scales on pectoral base except in rare cases.

There are remarkable differences in the adult size; individuals of more than $50 \mathrm{~mm}$ in standard length are very common in the populations of Shirahama and Ogasawara Islands, but are very rare in that of Nansei Islands. The maximum sizes of the specimens collected are 53.9, 82.9 and $71.6 \mathrm{~mm}$ for Types A, B and C respectively.

Colour of three types resembles with one another except a few trifles. Colour of Type A is nearly equal to Type B except subtle differences of colour pattern of fin membranes. Type $\mathrm{C}$ can be distinguished more easily from Types $\mathrm{A}$ and $\mathrm{B}$ by following respects: second, third and fourth transverse bands having short continuations into the basal part of dorsal fins; having a deep red spot just behind each jaw.

Almost all features of the specimens from Kagoshima Bay correspond to Type B, and Takagi's (1957) description on the types from Kagoshima Bay also agrees with Type B. In consequence, Takagi's species definitions of $A$. japonica necessarily includes only Type B, but disregards Types A and C. However, it is obvious from the above examinations that Types $\mathrm{A}$ and $\mathrm{C}$ are the intraspecific variations, though their differences from Type $\mathrm{B}$ are not trivial. The species definition of $A$. japonica must be revised to include all the features of three types.

\section{Discussion}

Geographical variations within the species of Amblyeleotris japonica are fairly distinct. Although they vary over wide ranges, some of meristic characters, such as the numbers of longitudinal scales and fin rays, have a trend to increase in Type B and Type C, in comparison with Type A. The same trend is also seen in body size, while relative length of head, and relative height of body and caudal peduncle show a reverse trend. The differences on these characters between Type A and Type B may be, bearing in mind Hubbs' (1940) theory, considered to be correlated with the differences in water temperatures between the two geographical areas. At 
Shirahama the water temperatures are about $5^{\circ} \mathrm{C}$ lower than at Nansei Islands in winter, whereas the water temperatures at Ogasawara Islands are similar to that at the latter. The differences between Type A or Type B and Type $\mathrm{C}$ can not be understood on the same basis for unknown reasons. As for some non-numerical characters, they are characteristic to each type and relatively invariable. The presence of pelvic frenum and scales on the median part of the nape are peculiar to Type $B$, and the development of uniting membrane in adult is to Type C.

It is not certain whether the differences among three types can be filled up geographically by the intermediate forms or not, as few specimens are at present available from the intermediate localities. However, Nansei Islands, Honshu and Kyushu, and Ogasawara Islands are geographically distant from each other and are well separated, with few islands in between, where suitable habitat for $A$. japonica is afforded. Three types can accordingly be regarded as substantial forms occupying more or less distinct geographical regions respectively. Thus, I consider that these three types should be assigned to the variations at subspecific level.

As for three species of the genus Amblyeleotris, namely A. maculata A. fasciata and A. japonica, the differences among them are distinct. $A$. maculata can be easily distinguished from other two species by its body colour pattern: some dark brown speckles irregularly scattered on the interspaces of transverse bands, and the outlines of these bands are uneven. These speckles and bands do not easily fade away in preserved specimens. A. fasciata also can be distinguished by its colouration, as it has many red spots on head, and dorsal and anal fins, and its transverse bands on body are dark reddish purple against dark brown in $A$. maculata and A. japonica. Red spots easily fade away in preserved specimens.

Because of the wide geographical variations of $A$. japonica, the variation ranges of the meristic and proportional characters of $A$. japonica overlap those of $A$. fasciata on one hand, and those of $A$. maculata on the other. Type A of $A$. japonica is relatively dumpy and resembles $A$. fasciata in proportional measurements: body height 198 and 202, head length 308 and 303, caudal peduncle height 110 and 111, predorsal 358 and 358, pre-second dorsal 557 and 551, prepelvic 357 and 340 , and preanal 590 and 585 respectively. Furthermore, the modal number of second dorsal and anal soft rays are 12 both in Type A of $A$. japonica and in A. fasciata. However, the former can be distinguished from the latter by the larger number of longitudinal scales (70,61 in average) and absence of embedded scales on the median part of nape and pectoral base (if present, they are very sparse), even if the differences of colour are ignored. Type $\mathrm{B}$ and Type $\mathrm{C}$ of $A$. japonica are slender and their proportional measurements are close to those of $A$. maculata: body height 172, 179 and 182 , head length 270,268 and 285, caudal peduncle height 98, 102 and 97, predorsal 323,340 and 337, pre-second dorsal 523, 538 and 546, prepelvic 327, 317 and 307, and preanal 564, 562 and 578 respectively. However, the differences among them are evident without considering colourlation: pelvic frenum is characteristic in Type B, the degree of the development of uniting membrane of Type $\mathrm{C}$ is superior to others, and the modal numbers of second dorsal and anal soft rays are different 
(Type B 13, 14, Type C 13, 13, A. maculata 12, 12).

The key to three species of the genus Amblyeleotris in Japan, together with that to three types of $A$. japonica, can be established as follow.

a. Outlines of five transverse bands uneven, and some speckles irregularly scattered on interspaces of bands.

D. VI-I, 12; A. I, 12; scales about 85 . No scales on median part of nape and pectoral base. Pelvic frenum absent, UM-value less than 0.15 .

Amblyeleotris maculata

$a^{\prime}$. Outlines of five transverse bands nearly straight, clear on interspaces of bands.

b. Band obviously broader than interspace.

D. VI-I, 12 (rarely 11); A. I, 12 (reraly 11); scales 55 to 70 . Small scales on median part of nape and pectoral base. Pelvic frenum absent, UM-value 0.2 to 0.65 .

$b^{\prime}$. Band narrower than (or as broad as) interspace.

Amblyeleotris fasciata

c. Short pelvic frenum present.

D. VI-I, 13 (rarely 12); A. I, 14 (rarely 13); scales 70 to 90 . Small scales on median part of nape, but sometimes absent; pectoral base scaleless except in rare cases. UMvalue less than 0.2 .

$c^{\prime}$. Pelvic frenum absent.

Type B of Amblyeleotris japonica

d. D. VI-I, 12 (rarely 11); A. I, 12; scales 65 to 80 . No scales on median part of nape, and pectoral base also scaleless except in rare cases. UM-value less than 0.3 .

Type A of Amblyeleotris japonica

d'. D. VI-I, 13 (rarely 14); A. I, 13 (rarely 14); scales 80 to 95 . No scales on median part of nape and pectoral base. UM-value 0.4 to 0.8 .

....... Type $\mathrm{C}$ of Amblyeleotris japonica

In the taxonomy of the gobioid fishes, the form of pelvic fins was traditionally regarded as important. The species which have united pelvic fins forming a disk constitute the family Gobiidae. The sleepers, with pelvic fins separated, are placed in the separate family Eleotridae. However, intermediate forms of pelvic fins include all the degree between the fully united and the perfectly separated. For instance, some species such as Callogobius hasselti (Bleeker) and C. liolepis Koumans have pelvic fins whose uniting membrane are not fully developed and notched at the posterior part (Takagi, 1963). Pelvic fins of some species such as Vireosa hanae Jordan et Snyder, Valenciennea strigatus (Brossonet) and Eviota abax (Jordan et Snyder) are separated for the most part, but are joined by a low uniting membrane only basally.

In recent years, the systematics of the gobioid fishes have been re-examined through the studies of osteology and comparative morphology (Gosline, 1955; Takagi, 1963; Hoese, 1967; Prince Akihito, 1969). Takagi (1963) tried to shift some genera from Eleotridae to Gobiidae on the basis of the number of branchiostegals. Prince Akihito (1969) divided the gobioid fishes into four groups on the bases of the following three features; the presence or absence of the mesopterygoid and of the upper postcleithrum, and the number of branchiostegals. In their studies, the genus Amblyeleotris, together with the genera Vireosa, Valenciennea, Eviota, Asteropteryx, 
etc., is transfered to the group in which the gobioid fishes having the united pelvic fins are included.

The form of pelvic fins is often variable within one genus or one species. For instance, all degree of fusion or separation of pelvic fins and all degrees of development of frenum exist in a single genus Coryphopterus in Bahamas (Böhlke and Chaplin, 1968). In the case of the mud skipper Periophthalmus cantonensis (Osbeck), the pelvic fins change as the animal grows; they are united to form a cup-like shape in the $14 \mathrm{~mm}$ juveniles, but are separated from each other at the posterior part by a deep notch formed on the posterior margin when the fish grows to the $31 \mathrm{~mm}$ young (Kobayashi et al., 1972). In Luciogobius elongatus Regan, the most individuals have the fleshy short united pelvic fins without pelvic frenum, but some have the frenum fully developed or half developed (Shiogaki and Dotsu, 1972).

In the three species of the genus Amblyeleotris mentioned in this paper, the variability of the pelvic fins is also remarkable. A short pelvic frenum is present only in Type $\mathrm{B}$ of $A$. japonica, but is entirely absent in all others. The degree of development of the uniting membrane varies among the species and the subspecies, and moreover, it changes as the animal grows. As has been stated elsewhere, it is most drastically represented in Type B of $A$. japonica: the juveniles of about $10 \mathrm{~mm}$ have the fully developed uniting membrane, so the pelvic fins are disk-like shaped, but the uniting membrane suddenly reduces to make the pelvic fins separated when the fish grows more than about $12 \mathrm{~mm}$. These phenomena suggest that $A$. japonica once had a disk-like fin, and the fins are secondarily separated in its phylogeny. This supports the view that the genus Amblyeleotris is related more closely to the group having disk-shaped pelvic fins rather than to the group with fully separated fins such as the genera Eleotris and Odontobutis.

Three species of the genus Amblyeleotris treated in this paper have the closest affinities with one another in the behaviour and the morphological characters. These three species are distinguishable from the genotype Amblyeleotris periophthalmus Bleeker by the colour pattern and the width of gill opening. A. periophthalmus have 6 pink transverse bands, the first on opercle, second from dorsal to pelvic fin, third, fourth and fifth from dorsal to anal fin, sixth on caudal peduncle (Koumans, 1953), while three Japanese species have only 5 dark brown or dark reddish purple bands. The gill opening of the former is lateral or slightly more, that is much narrower than the latter.

Judging from Smith's (1958) description, the greater part of the features of Cryptocentrops exilis Smith seem to correspond to those of the genus Amblyeleotris in Japan, except wide gill opening extending to below eye. This species has 5 brown transverse bands at the same position to Amblyeleotris in Japan. It is doubtful whether Cryptocentrops is the separate genus from Amblyeleotris. Faulkner and Smith (1970) give a photograph of the goby Cryptocentrus sp. and the snapping shrimp Alpheus djiboutensis in association in Palau Islands. This goby has the transverse bands at the same position to the genus Amblyeleotris in Japan, and seems to have the separate pelvic fins. There is some possibility that this species is another species of the genus 
Amblyeleotris rather than the genus Cryptocentrus. The genus Amblyelotris is relatively close to the genera Cryptocentrus, Smilogobius, Mars and Obtortiophagus, which contain the species associating with the snapping shrimps, and Smith (1958) suggested the affinity between the genera Cryptocentrus and Cryptocentroides. The detailed morphological and ecological studies about these genera are desirable.

\section{Summary}

1. New species Amblyeleotris maculata was described on the three specimens collected at the shallow water of Sesoko Island, Okinawa Island, and A. fasciata (Herre) which is recorded for the first time from Japanese water was re-described on the specimens from Nansei Islands and Ogasawara Islands.

2. Amblyeleotris japonica Takagi has the remarkable variations among three populations of Nansei Islands, Shirahama and Ogasawara Islands. These geographical variations were analysed chiefly based on the number of fin rays and scales, the proportional characters, the form of pelvic fins and presence or absence of the scales of the median part of nape and those of pectoral base.

3. The developmental changes of pelvic fins is remarkable in A. japonica collected at Shirahama. The uniting membrane of juveniles about $10 \mathrm{~mm}$ in standard length is fully developing and the form of pelvic fins is disk-like, but that of specimens growing up more than $12 \mathrm{~mm}$ reduces suddenly and pelvic fins become separated.

4. The morphoiogical characters of $A$. maculata, $A$. fasciata and three geographical types of $A$. japonica were compared and the key to these species and types were established.

\section{REFERENCES}

Akihito, Prince, 1969. A systematic examination of the gobiid fishes based on the mesopterygoid, postcleithra, branchiostegals, pelvic fins, scapula, and suborbital. Japan. J. Ichthyol., 16 (3): 93-114. (In Japanese).

Bleeker, P. 1853. Diagnostische beschrijvingen van nieuwe of weining bekende vischsoorten van Batavia. Tiental I-VI. Naturkundig Tijdschrift voor Nederlandsch-Indië, 4: 451-516.

1874. Notice sur les genres Amblyeleotris, Valenciennesia et Brachyeleotris. Koninklijke Akademie van Wetenschappen, Verslagen en Mededeelingen, Afdeeling Natuurkunde, 2 (8): 372-376.

Böhlke, J.E. and C. C. G. Chaplin, 1968. Fishes of the Bahamas and adjacent tropical waters. XXX +771 pp. 36 pls., Livingston, Wynnewood.

Faulkner, D. and C. L. Smith, 1970. The hidden sea. 149 pp. Viking Press, New York.

Gosline, W. A. 1955. The osteology and relationships of certain gobioid fishes, with particular reference to the genera Krameria and Microdesmus. Pacific Sci., 9: 158-170.

Harada, E. 1969. On the interspecific association of a snapping shrimp and gobioid fishes. Publ. Seto Mar. Biol. Lab., 16 (5) : 315-334.

1972. On the interspecific associations between snapping shrimps and gobioid fishes, observed in coastal areas of Nansei Islands. Biol. Mag. Okinawa, 9: 1-8. (In Japanese).

Herre, A. W. C. T. 1943. Notes on fishes in the Zoological Museum of Stanford University. XI. Two new genera and species, with key to the genera of gobies with vomerine teeth. Proc. Biol. 
Soc. Wash. 56: 91-96.

1945. Notes on fishes in the Zoological Museum of Stanford University. XIX. Two new Philippine gobies, with key to the genera of gobies with vomerine teeth. Ibid. 58: 77-82.

1953a. The tropical Pacific Eleotridae with vomerine teeth with descriptions of two new genera and two new species from the Marshall Islands. Philip. J. Sci. 82 (2): 189-192. 373. 1953b. The eleotrid gobies of the Philippines and adjacent regions. Ibid. $82(4): 345-$

Hoese, D. F. 1967. Morphological differences between the families Gobiidae and Eleotridae. Abstr. Ichtyol., Am. Soc. Ichtyol. Herpetol., 47th Annual Meeting: 13.

Hubbs, C. L. 1940. Speciation of fishes. Amer. Naturalist, 74: 198-211.

- and K. F. Lagler, 1958. Fishes of the Great Lakes Region. Bull. Cranbrook Inst. Sci., 26, 213 pp.

Karplus, I., R. Szlep and M. Tsurnamal, 1972. Associative behavior of the fish Cryptocentrus cryptocentrus (Gobiidae) and the pistol shrimp Alpheus djiboutensis (Alpheidae) in artificial burrows. Mar. Biol., 15 (2) : 95-104.

Kobayashi, T., Y. Dotsu and N. Miura, 1972. Egg development and rearing experiments of the larvae of the mud skipper Periophthalmus cantonensis. Bull. Fac. Fish. Nagasaki Univ., 33: 49-62. (In Japanese).

Koumans, F. P. 1953. Gobioidea. The fishes of the Indo-Australian Archipelago, X. xiii +423 pp., 95 figs., Leiden.

Luther, W. 1958. Symbiose von Fischen (Gobiidae) mit einem Krebs (Alpheus djiboutensis) im Roten Meer. Z. f. Tierpsychol., 15 (2): 175-177.

Magnus, W. B. E. 1967. Zur Ökologie sedimentbewohnender Alpheus-Garnelen (Decapoda, Natantia) des Roten Meeres. Helgoländer wiss. Meeresunters., 15 (1-4) : 506-522.

Shiogaki, M. and Y. Dotsu, 1972. The life history of the gobiid fish, Luciogobius elongatus. Bull. Fac. Fish. Nagasaki Univ., 34: 9-18. (In Japanese).

Smith, J. L. B. 1958. The fishes of the family Eleotridae in the Western Indian Ocean. Ichthyol. Bull., 11: 137-163.

Takagi, K. 1957. Descriptions of some new gobioid fishes of Japan, with a proposition on the sensory line system as a taxonomic character. J. Tokyo Univ. Fish., 43 (1): 97-126, pls. 5. 6.

1963. Studies of the gobioid fishes in the Japanese waters on the comparative morphology, phylogeny, taxonomy, distribution and bionomics. 273 pp., figs. 47, Tokyo. (Mimeograph in Japanese).

Weber, M. 1913. Die Fische der Siboga-Expedition. Siboga-Expeditie, Mon. 57, xii +710 pp., 123 figs., 12 pls., Leiden. 